\title{
PENGARUH STRUKTUR MODAL DAN UKURAN PERUSAHAAN TERHADAP MANAJEMEN LABA PADA PERUSAHAAN PERTAMBANGAN DAN KONSTRUKSI YANG TERDAFTAR DI BURSA EFEK INDONESIA
}

\author{
Afni Eliana Saragih, S.E., M.Si
}

\begin{abstract}
Abstrak
Laba perusahaan digunakan oleh pihak eksternal sebagai indikator kinerja operasional perusahaan.Oleh sebab itu adalah menjadi hal yang penting bagi perusahaan untuk menyajikan laba yang sesuai dengan harapan pihak yang berkepentingan. Laba dapat dikatakan berkualitas tinggi jika laba yang dilaporkan tersebut dapat digunakan oleh pengguna laporan keuangan untuk membuat keputusan yang terbaik dan memenuhi karakteristik kualitatif laporan keuangan yaitu relevan, dapat dipahami, andal dan dapat diperbandingkanPenelitian ini bertujuan untuk memberikan bukti empiris pengaruh struktur modal dan ukuran perusahaan terhadap manajemen laba. Struktur modal diukur dengan menggunakan rasio leverage dan ukuran perusahaan diperoleh dengan logaritma natural asset. Discretionary accrual digunakan sebagai proksi manajemen laba.Sampel penelitian adalah 8 perusahaan pertambangan dan konstruksi yang terdaftar di Bursa Efek Indonesia, yang dipilih menggunakan random acak sederhana selama periode penelitian, tahun 2010-2015.Data dianalisis menggunakan regresi berganda.Berdasarkan hasil pengujian disimpulkan bahwa struktur modal dan ukuran perusahaan tidak berpengaruh signifikan terhadap manajemen laba.Perusahaan dengan tingkat leverage yang tinggi akibat besarnya total hutang terhadap total modal akan menghadapi resiko default yang tinggi yaitu perusahaan terancam tidak mampu memenuhi kewajibannya. Tindakan manajemen laba tidak dapat dijadikan sebagai mekanisme untuk menghindarkan default tersebut.Pemenuhan kewajiban harus tetap dilakukan dan tidak dapat dihindarkan dengan manajemen laba.
\end{abstract}

Kata kunci : manajemen laba, discretionaryaccrual, struktur modal, rasio leverage, ukuran perusahaan

\section{PENDAHULUAN}

Manajer sebagai pihak internal, pihak yang melakukan transaksi dan menyusun laporan keuangan, memiliki informasi jauh lebih banyak dibandingkan dengan pihak eksternal.Kondisi ini sering disebut dengan asimetry informasi (information asymmetry).Hal ini memungkinkan manajemen perusahaan untuk melaporkan laba yang tidak menggambarkan kondisi perusahaan yang sesungguhnya disebut dengan manajemen laba (earnings management).Umumnya manajemen selaku pihak insider melakukan manajemen laba untuk kepentingan pribadi, misalnya untuk mendapatkan bonus.

Ardekani (2012) mendefenisikan manajemen laba ke dalam tiga defenisi berikut dalam rangka memahami konsep manajemen laba lebih jelas. Pertama, 
manajemen laba merupakan sebuah alat yang digunakan untuk fleksibilitas informasi akuntansi yang diaplikasikan oleh manajer sebagai sinyal akan informasi ekslusif yang mereka miliki sebagai pengelola perusahaan kepada pemangku kepentingan lainnya. Kedua, manajemen laba merupakan alat dalam akuntansi dimana dengan alat tersebut manajer dapat diaplikasikan baik dalam aspek oppurtunis maupun optimis. Ketiga, manajemen laba merupakan manipulasi data akuntansi yang mengarah kepada menurunnya transparansi laporan keuangan dan dapat menyesatkan investor dan pemangku kepentingan lain dalam mengambil keputusan yang pada akhirnya memberikan keuntungan bagi manajer.

Manajemen laba telah menjadi perdebatan yang panjang sejak tahun 1980-an, ketika diinvestigasi melalui penelitian.Fokus utama penelitan akhir-akhir ini terkait manajemen laba adalah mengidentifikasi faktor-faktor yang memotovasi manajemen untuk melakukan praktik manajemen laba. Beberapa penelitian menemukan, motif manajemen melakukan manajemen laba adalah digerakkan demi memperoleh jumlah upah atau imbalan, posisi sebagai manajemen, mencapai target atau ekspektasi pasar, menjaga stabilitas harga, penghindaran pajak, profit smoothing, memenuhi suatu peraturan tertentu, mencapai syarat kontrak yang telah ditetapkan, menghindari pembayaran dividend dan mempersiapkan perusahaan untuk merger.

Ajit et al,.(2013) melakukan penelitian terkait manajemen laba di India.Hasil penelitiannya menemukan bahwa perusahaan dengan skala kecil melakukan manajemen laba lebih tinggi dibandingkan dengan perusahaan dengan skala sedang dan skala besar. Jika dilihat dari kategori jenis industri, perusahaan pertambangan dan konstruksi cenderung melakukan manajemen laba lebih tinggi dibandingkan dengan jenis industri lain. Ujah dan Brusa (2010) menganalisis faktor yang mendorong perusahaan melakukan manajemen laba yang dikaitan dengan tingkat leverage dan volatilitas arus kas perusahaan dalam kondisi perekonomian yang mempengaruhi perusahaan. Hasil penelitian tersebut menemukan bahwa financial leverage, yang mengarah pada struktur modal, dan cash flow mempengaruhi tingkat keterlibatan manajemen untuk melakukan manajemen laba.

Penelitian ini akan menguji apakah struktur modal dan ukuran perusahaan mempengaruhi manajemen untuk melakukan manajemen laba atau tidak. Penelitian ini memberikan implikasi yang penting bagi pemangku kepentingan maupun badan yang berwenang membuat peraturan karena kualitas informasi akuntansi telah menjadi bagian yang sangat penting dalam situasi yang terjadi saat ini.Oleh sebab itu penelitian terkait manajemen laba menjadi isu yang menarik tidak hanya di Indonesia, tetapi juga di seluruh dunia.Melihat situasi bisnis saat ini, struktur modal, ukuran perusahaan dan manajemen laba telah menjadi sangat penting.Diprediksi terdapat pengaruh yang kuat antara struktur modal dan ukuran perusahaan terhadap manajemen laba. 
Sesuai dengan pemaparan latar belakang di atas maka penelitian ini akan menganalisis aspek yang digunakan oleh perusahaan untuk memanipulasi laba dan karaktersistik perusahaan tertentu, yang dilihat dari struktur modal dan ukuran perusahaan. Penelitian yang komprehensif terkait topik ini mengarahkan peneliti untuk menganalisis apakah dampak ukuran perusahaan terhadap manajemen laba dan bagaimana struktur modal mempengaruhi manajemen melakukan manajemen laba. Lebih lanjut, penelitian ini akan melihat manakah dari kedua variabel independen tersebut akan lebih banyak mempengaruhi manajemen laba.

\section{TELAAH PUSTAKA}

\section{Manajemen Laba}

Menurut Sulistyanto (2008) Manajemen laba merupakan upaya manajer perusahaan untuk mengintervensi atau mempengaruhi informasi-informasi dalam laporan keuangan dengan tujuan untuk mengelabui stakeholder yang ingin mengetahui kinerja dan kondisi perusahaan.Istilah intervensi dan mengelabui inilah yang dipakai sebagai dasar sebagian pihak untuk menilai manajemen laba sebagai kecurangan. Sementara pihak lain tetap menganggap aktivitas rekayasa manajerial ini bukan sebagai kecurangan. Alasannya, intervensi itu dilakukan manajer perusahaan dalam kerangka standar akuntasi, yaitu masih menggunakan metode dan prosedur akuntansi yang diterima dan diakui secara umum.

Dechow \& Skinner (2000) menyebutkan bahwa manajemen laba terjadi ketika manager menggunakan estimasi (judgment) dalam pelaporan keuangan dan menyesuaikan transaksi tertentu untuk mengubah laporan keuangan untuk menyesatkan pemegang kepentingan terkait kinerja perusahaan yang berada di bawah standard, atau untuk mempengaruhi hasil kerja perusahaan yang bergantung pada angka akuntansi dalam laporan keuangan. Tujuan yang akan dicapai oleh manajemen melalui manajemen laba meliputi: mendapatkan bonus dan kompensasi lainnya, mempengaruhi keputusan pelaku pasar modal, menghindari pelanggaran perjanjian hutang, dan juga menghindari biaya.

\section{Motivasi Manajemen Laba (Earnings Management)}

Menurut Scott (2009), manajemen laba adalah pilihan kebijakan akuntansi oleh manajer untuk mencapai tujuan tertentu. Earnings Management berkaitan dengan pemilihan metode akuntansi sehingga manajemen tentunya akan memilih metode tertentu yang dianggap menguntungkan. Hal ini dapat dijelaskan oleh Positive Accounting Theory (PAT) menurut Watts dan Zimmerman (1986) dalam Deegan (2007) bahwa teori ini menjelaskan dengan detail bagaimana praktik akuntansi, menjelaskan dan memprediksi metode tertentu yang akan dipilih dan yang tidak akan dipilih perusahaan.

Hipotesis Positive Accounting Theory (PAT) mengenai motivasi manajemen laba dalam bukunya Scott (2009) menuliskan ada tiga, yaitu : 
a. Hipotesis program bonus (Bonus Plan Hypothesis)

Bonus plan hypothesis menyatakan bahwa "managers of firms with bonus plans are more likely to use accounting methods that increase current periode reported income". Artinya manager perusahaan yang memanfaatkan bonus cenderung lebih menggunakan metode akuntansi yang akan meningkatkan jumlah laba periode ini. Dalam bonus atau kompensasi manajerial, pemilik perusahaan berjanji bahwa manajer akan menerima sejumlah bonus jika kinerja perusahaan mencapai jumlah tertentu. Janji bonus inilah yag merupakan alasan bagi manajer untuk mengelola dan mengatur labanya pada tingkat tertentu sesuai dengan yang disyaratkan agar dapat menerima bonus.

Seandainya pada tahun tertentu kinerja sesungguhnya berada di bawah syarat untuk memperoleh bonus, maka manajer akan melakukan manajemen laba agar labanya dapat mencapai tingkat minimal untuk memperoleh bonus. Sebaliknya, jika pada tahun itu kinerja yang diperoleh manajer jauh di atas jumlah yang disyaratkan untuk memperoleh bonus, manajer akan mengelola dan mengatur agar laba yang dilaporkan menjadi tidak terlalu tinggi. Kelebihan laba sesungguhnya dengan laba yang dilaporkan akan disajikan pada tahun berikutnya. Upaya ini membuat manajer cenderung akan selalu memperioleh bonus dari periode ke periode. Akibatnya, pemilik perusahaan terpaksa harus kehilangan sebagian dari kesejahteraannya yang dibagikan kepada manajer sebagai bonus.

\section{b. Hipotesis perjanjian utang (Debt Equity Hypothesis)}

Debt equity hypothesis menyatakan bahwa "the larger the firms debt to equity ratio, the more likely managers use accounting methods that increase income". Artinya semakin tinggi rasio utang terhadap ekuitas perusahaan, manajer akan cenderung menggunakan metode akuntansi yang meningkatkan laba. Dalam konteks perjanjian utang, manajer akan mengelola dan mengatur labanya agar kewajiban hutangnya yang seharusnya diselesaikan pada tahun tertentu dapat ditunda untuk tahun berikutnya. Hal ini merupakan upaya manajer untuk mengelola dan mengatur jumlah laba yang merupakan indikator kemampuan perusahaan dalam menyelesaikan kewajiban utangnya. Manajer akan melakukan pengelolaan dan pengaturan jumlah laba untuk menunda bebannnya pada periode bersangkutan dan akan diselesaikannya pada periode-periode mendatang.

Upaya seperti ini dilakukan agar perusahaan dapat menggunakan dana tersebut untuk keperluan lainnya. Walau sebenarnya hanya masalah waktu pengakuan (timing) kewajiban, hal ini telah mengakibatkan pihak yang ingin mengetahui kondisi perusahaan yang sesungguhnya akan memperoleh dan meggunakan informasi yang keliru. Akibatnya pihak-pihak ini membuat keputusan bisnis yang keliru pula.

c. Hipotesis biaya politik (Political Cost Hypothesis/ Size Hypothesis)

Political cost hypothesis menyatakan bahwa "larger firms rather than small firms are more likely to use accounting choices that reduce reported profits". 
Artinya, perusahaan yang berskala besar lebih menggunakan pilihan akuntansi untuk mengurangi pelaporan keuntungan dibandingkan dengan perusahaan dengan skala kecil.Hipotesis ini berkaitan dengan regulasi pemerintah, misalnya undang-undang perpajakan. Besar kecilnya pajak yang akan ditagih oleh pemerintah sangat tergantung pada besar kecilnya laba yang dicapai perusahaan. Kondisi inilah yang merangsang manajer untuk mengelola dan megatur labanya dalam jumlah tertentu agar pajak yang harus dibayarkannnya menjadi tidak terlalu tinggi, karena manager sebagai pengelola tidak ingin kewajiban yang harus diselesaikannnya terlalu membebaninya.

Upaya yang mungkin dilakukan manajer adalah menarik biaya periode yang akan datang menjadi biaya periode berjalan dan sebaliknya mengakui pendapatan periode berjalan menjadi pendapatan periode yang akan datang. Upaya lain yang dilakukan perusahaan untuk menghemat pajak adalah dengan mempermainkan laba pada saat ada pergantian peraturan perundang-undangan yang memberlakukan tarif pajak lebih rendah di masa depan. Perusahaan menunda pengakuan laba periode berjalan dan baru akan diakui pada saat peraturan yang baru itu diberlakukan secara efektif.

\section{Teknik Manajemen Laba}

Manajemen laba dapat dilakukan dengan tiga teknik (Azhari, 2015) yaitu:

a. Perubahan metode akuntansi

Manajemen mengubah metode akuntansi yang berbeda dengan metode sebelumnya sehingga dapat menaikkan atau menurunkan angka laba. Metode akuntansi memberikan peluang bagi manajemen untuk mencatat suatu fakta tertentu dengan cara yang berbeda, misalnya:

- Mengubah metode depresiasi aktiva tetap dari metode jumlah angka tahun (sum of the year digit) ke metode depresiasi garis lurus (straight line)

- Mengubah periode depresiasi

b. Memainkan kebijakan perkiraaan akuntansi

Manajemen mempengaruhi laporan keuangan dengan cara memainkan kebijakan perkiraan akuntansi. Hal tersebut memberikan peluang bagi manajemen untuk melibatkan subjektivitas dalam menyusun estimasi, misalnya:

- Kebijakan mengenai perkiraan jumlah piutang tidak tertagih

- Kebijakan mengenai perkiraan biaya garansi

- Kebijakan mengenai perkiraan terhadap proses pengadilan yang belum terputuskan.

c. Menggeser periode biaya atau pendapatan

Manajemen menggeser periode biaya atau pendapatan atau sering disebut manipulasi keputusan operasional, misalnya: 
- Mempercepat atau menunda pengeluaran untuk penelitian dan pengembangan sampai periode akuntansi berikutnya.

- Mempercepat atau menunda pengeluaran promosi sampai periode berikutnya.

- Kerjasama dengan vendor untuk mempercepat atau menunda pengiriman tagihan sampai periode akuntansi berikutnya.

- Menjual investasi sekuritas untuk memanipulasi tingkat laba.

- Mengatur saat penjualan aktiva tetap yang sudah tidak terpakai.

\section{Struktur Modal}

Mengacu pada penelitian Azhari (2015), leverage sebagai rasio proksi dari struktur modal. Faktor leverage adalah rasio antara nilai buku seluruh hutang $($ debt $=\mathrm{D})$ terhadap total aktiva (total aset $=\mathrm{TA}$ ) atau nilai total perusahaan. Bila membahas tentang total aktiva, yang dimaksudkan adalah total nilai buku dari aktiva perusahaan berdasarkan catatan akuntansi. Nilai total perusahaan berarti total nilai pasar seluruh komponen struktur modal perusahaan. Rasio leverage merupakan rasio untuk mengukur seberapa bagus struktur permodalan perusahaan. Struktur permodalan merupakan pendanaan permanen yang terdiri dari hutang jangka panjang, saham preferen dan modal pemegang saham.

Struktur modal biasanya diukur dengan leverage karena untuk mengetahui seberapa besar aset perusahaan yang dibiayai oleh hutang perusahaan. Rasio leverage dapat menunjukkan risiko yang ditanggung oleh perusahaan. Perusahaan yang memiliki hutang yang tinggi bisa berdampak pada risiko keuangan yang semakin besar.Risiko keuangan yang dimaksud adalah kemungkinan perusahaan tidak mampu membayar utang-utangnya. Adanya risiko gagal bayar ini menyebabkan biaya yang harus dikeluarkan perusahaan untuk mengatasi hal tersebut semakin besar sehingga akan menurunkan laba perusahaan. Oleh karena itu, jika tingkat leverage suatu perusahaan tinggi maka akan memiliki kecenderungan untuk melakukan manajemen laba yang besar sehingga kualitas laba yang dihasilkan menjadi rendah. Mengacu pada penelitian Agustina (2013) mengukur rasio leverage dihitung dengan persamaan berikut ini.

$$
\text { Rasio Leverage }=\frac{\text { NetLiabilities }}{\text { TotalAssets }}
$$

\section{Ukuran Perusahaan}

Ukuran perusahaan akan mempengaruhi struktur pendanaan perusahaan tersebut. Perusahaan dengan skala besar cenderung membutuhkan dana yang lebih besar dibandingkan perusahaan dengan skala kecil. Oleh sebab itu perusahaan dengan ukuran besar umumnya membutuhkan tambahan dana untuk operasionalnya. Kebutuhan dana tersebut dapat diperoleh melalui penerbitan saham baru atau menambah jumlah utang. Untuk mendapatkan dana dari pihak eksternal baik penerbitan saham maupun utang dibutuhkan kepercayaan investor akan pengembalian dana atas investasinya dari perusahaan. Dengan demikian 
manajemen mungkin melakukan manajemen laba untuk menunjukkan laporan keuangan yang diinginkan untuk mendapat kepercayaan investor.

Berdasarkan size hypothesis yang dalam penelitiannya, Agustina (2013) bersasumsi bahwa perusahaan besar secara politis, lebih besar dibandingkan dengan perusahaan kecil. Ukuran perusahaan dalam penelitian ini menggunakan proksi log natural dari total asset. Total asset digunakan sebagai proksi ukuran perusahaan dengan pertimbangan total asset relative lebih stabil dibandingkan dengan ukuran perusahaan lainnya seperti total penjualan dan kapitalisasi pasar (Guna dan Herawaty, 2010).

\section{Pengembangan Hipotesis}

a. Pengaruh Struktur Modal Terhadap Manajemen Laba

Struktur modal dalam penelitian ini dilihat dari tingkat leverage perusahaan. Semakin besar tingkat leverage perusahaan, maka manajer cenderung akan berusaha menunjukkan kinerja yang baik. Jika kinerja keuangan perusahaan tidak berhasil sesuai dengan target yang telah ditetapkan di awal, maka dapat mengurangi kepercayaan kreditur terhadap perusahaan. Di samping itu apabila target yang ditentukan tidak terpenuhi dapat mendorong manajer melakukan tindakan oppurtunistik yaitu melaporkan laba lebih tinggi dari yang seharusnya yang disebut dengan tindakan manajemen laba. Tindakan ini dilakukan untuk meyakinkan kreditur agar bersedia menginvestasikan dananya ke dalam perusahaan.sekalipun tindakan tersebut tidak menunjukkan laba yang sesungguhnya (Wibisana, 2014)

Jao dan Pagalung (2010) menyatakan dakan debt covenant hypothesis bahwa semakin dekat perusahaan ke arah pelanggaran persyaratan utang yang didasarkan atas angka akuntansi maka manajer lebih cenderung untuk memilih prosedur akuntansi yang memindahbukukan laba periode mendatang ke periode berjalan. Dengan demikian dinyatakan terdapat pengaruh positif leverage terhadap manajemen laba.Guna dan Herawaty (2010) menyatakan bahwa semakin tinggi nilai leverage maka risiko yang akan dihadapi investor akan semakin tinggi. Dengan demikian investor akan meminta return atau pengembalian yang lebih tinggi juga. Hal ini mengingat didalam risiko yang tinggi dituntut pengembalian yang tinggi. Oleh karena itu semakin besar leverage maka kemungkinan manajer melakukan manajemen laba akan semakin besar. Dengan demikian hipotesis pertama dinyatakan sebagai berikut:

H1 : Struktur modal berpengaruh positif signifikan terhadap manajemen laba.

\section{b. Pengaruh Ukuran Perusahaan Terhadap Manajemen Laba}

Ukuran perusahaan berpengaruh positif dengan manajemen laba.Pertama, ukuran perusahaan umumnya berkaitan dengan system pengendalian internal.Perusahaan dengan ukuran yang lebih besar memiliki pengendalian internal yang lebih kompleks dibandingkan dengan perusahaan dengan ukuran yang lebih kecil.System pengendalian internal yang efisien memungkinkan 
perusahaan untuk mengungkapkan informasi yang akurat kepada publik.Salah satu faktor penting yang dapat mengurangi terjadinya manajemen laba dan meningkatkan kualitas pelaporan keuangan adalah tata kelola perusahaan (corporate governance) (Warfield, et al., 1995). Menurut Beasly et al., (2000) mayoritas dari perusahaan yang tidak jujur tentang kesehatan perusahaanya, kurang didukung oleh audit internal dan memiliki mekanisme tata kelola perusahaan yang lemah.

Kedua, perusahaan besar diaudit oleh Kantor Akuntan Publik (KAP) yang besar juga. KAP tersebut memiliki pengalaman dan kapabilitas dalam audit sehingga mudah mendeteksi adanya manajemen laba. Menurut penelitian Gore, et al., (2001) auditor KAP yang non big 5 mengabaikan manajemen laba lebih besar dibandingkan dengan auditor KAP yang big 5.Selain itu perusahaan yang diaudit oleh KAP big 5 melaporkan manajemen laba yang dilihat dari discretionary accrual yang lebih rendah (Becker, et al., 1988; Payne and Robb, 2000).

Perusahaan dengan ukuran yang lebih besar cenderung lebih diminati oleh analis dan broker karena umumnya melaporkan laba yang stabil. Dugaan tersebut didasari oleh pemikiran bahwa perusahaan besar lebih diperhatikan oleh analis, investor dan pemerintah. Oleh karena itu perusahaan besar akan menghindari fluktuasi laba yang terlalu drastis, karena kenaikan laba yang drastis akan menyebabkan kenaikan pajak. Sebaliknya, penurunan laba yang drastis akan memberikan pandangan yang kurang baik sebab kinerja perusahaan dianggap mengalami penurunan kinerja (Januarti dan Corolina, 2005). Dengan demikian hipotesis kedua dinyatakan sebagai berikut:

H2 : Ukuran perusahaan berpengaruh negatif signifikan terhadap manajemen laba.

\section{METODE PENELITIAN}

\section{Populasi dan Sampel}

Populasi penelitian ini adalah seluruh perusahaan pertambangan dan konstruksi yang terdaftar di Bursa Efek Indonesia tahun 2010-2015. Total 32 perusahaan pertambangan dan konstruksi yang terdaftar di Bursa Efek Indonesia hingga tahun 2015.Sampel merupakan bagian dari populasi yang diambil melalui cara-cara tertentu, jelas dan lengkap (Sekaran, 2006). Tehnik pengambilan sampel dalam penelitian ini adalah menggunakan tehnik pengambilan sampel acak sederhana dengan periode pengamatan lima (5) tahun. Perusahaan akan dijadikan sampel apabila memenuhi ketersediaan data yang dibutuhkan dalam penelitian yaitu, laba bersih, total hutang, total asset, kas dari operasional, pendapatan, piutang bersih, aktiva tetap tanah, gedung dan peralatan. Desain pengambilan sampel ini dipilih karena generalisasi temuan pada seluruh populasi merupakan tujuan penelitian ini. 


\section{Variabel dan Defenisi Operasional Variabel}

Variabel dependen dalam penelitian ini adalah manajemen laba dengan proksi discretionary accruals. Variabel independen dalam penelitian ini adalah struktur modal dengan proksi leverage, ukuran perusahaan dengan proksi log total of asset. Operasionalisasi dari masing-masing variabel adalah sebagai berikut :

1. Manajemen laba

Manajemen laba dalam penelitian ini diukur dengan proksi discretionary accruals menggunakan model Modified Jones. Langkah-langkah menghitung discretionary accruals modified Jones (Ajit, 2013):

a. Total Accruals

$$
\text { TACCit }=\text { EBXTit }- \text { OCFit }
$$

Keterangan:

TACCit : Total accruals pada tahun $\mathrm{t}$

EBXTit : Laba bersih perusahaan i pada tahun $\mathrm{t}$

OCFit : Arus kas dari aktivitas operasi (operating cash flow) perusahaan i pada tahun $\mathrm{t}$

Estimasi dari parameter spesifik perusahaan, diperoleh melalui model analisis regresi OLS (Ordinary Least Squares) berikut ini:

TACCit/TAi,t-1 = $\alpha 1(1 /$ TAi,t-1) $+\alpha 2((\Delta$ REVit $-\Delta$ RECit $) /$ TAi,t-1) $+\alpha 3($ PPEit/

$$
\text { TAi,t-1) }
$$

Keterangan:

TACCit : Total accruals pada tahun $\mathrm{t}$

TAi,t-1 : Total assets untuk sampel perusahaan i pada akhir tahun t-1

$\triangle$ REVit : Perubahan pendapatan (revenue) perusahaan i dari tahun t-1 ke tahun $\mathrm{t}$

$\triangle$ RECit : Perubahan piutang bersih (net receivable) perusahaan i dari tahun t-1 ke tahun $\mathrm{t}$

PPEit : Gross property, plant and equipment perusahaan i pada tahun $\mathrm{t}$

b. Non Discretionary Accruals

NDACCit $=\alpha 1(1 /$ TAi,t-1 $)+\alpha 2((\Delta$ REVit $-\Delta$ RECit $) / T A i, t-1)+\alpha 3($ PPEit $/ T A i, t-1)$

Keterangan:

NDACCit : Non discretionary accruals pada tahun $t$

TAi,t-1 : Total assets untuk sampel perusahaan i pada akhir tahun t-1

$\triangle \mathrm{REVi} \quad$ : Perubahan pendapatan (revenue) perusahaan i dari tahun t-1 ke tahun $\mathrm{t}$

$\triangle$ RECit $\quad$ : Perubahan piutang bersih (net receivable) perusahaan i dari tahun t-1 ke tahun $\mathrm{t}$

PPEit : Gross property, plant and equipment perusahaan i pada tahun $\mathrm{t}$

c. Discretionary Accruals

DACCit $=($ TACCit $/$ AAi,t-1 $)-$ NDACCit 
Keterangan:

DACCit : Discretionary accruals perusahaan i pada tahun $\mathrm{t}$

2. Ukuran perusahaan

Ukuran perusahaan (size) dalam penelitian ini diukur dengan menggunakan logaritma natural of total assets.

3. Struktur modal

Lavarage $=$ Total Debt $/$ Total Asset

\section{Teknik Analisis Data}

Metode statistik yang digunakan untuk menguji hipotesis adalah regresi berganda (multipleregression). Berdasarkan penelitian terdahulu dan teori yang telah diuraikan sebelumnya, model matematis yang dikonversi menjadi model regresi sebagai berikut:

$\mathrm{EM}_{\mathrm{it}}=\alpha \mathrm{O}+\beta_{1} \mathrm{Lev}_{\mathrm{it}}+\beta_{2} \mathrm{Asst}_{\mathrm{it}}+\varepsilon$

Keterangan:

$\mathrm{EM}_{\mathrm{it}}=$ Manajemen laba (earnings management), diukur melalui discretionary accruals yang dihitung dengan cara menghitung selisihtotal accruals (TAC) dan non discretionary accruals (NDAC).

$\mathrm{LEV}_{\mathrm{it}}=$ Struktur Modal yang diukur dengan tingkat leverage perusahaan

$\mathrm{ASST}_{\mathrm{it}}=$ Total aktiva perusahaan, diukur dengan cara menjumlahkan semua kekayaan yang dimiliki oleh suatu perusahaan dalam kurun waktu tertentu.

A $\quad=$ konstanta

$\varepsilon \quad=$ error

Penggunaan persamaan regresi berganda dimaksudkan untuk memperkirakan adanya pengaruh yang signifikan dari manajemen laba. Metode analisis yang digunakan adalah regresi berganda. Dalam melakukan analisis regresi berganda, juga akan dilakukan pengujian hipotesis dengan menggunakan pengujian asumsi klasik, seperti uji normalitas data, heteroskedastisitas dan autokorelasi suatu kesalahan random dari model dan menguji tingkat multikolinearitas antar variabel independen.

\section{HASIL PENELITAN DAN PEMBAHASAN}

\section{Statistik Deskriptif}

Hipotesis dalam penelitian ini diuji dengan menggunakan metode regresi liner berganda. Tujuan dari pengujian metode itu adalah untuk mengetahui pengaruh variabel independen yang terdiri dari struktur modal yang diukur dari tingkat leverage,dan ukuran perusahaan terhadap variabel dependen yaitu manajemen laba (earnings management).Penelitian statistik deskriptif memberikan gambaran dari suatu data yang dilihat dari nilai rata-rata (mean), 
standar deviasi, varian, maksimum, minimum, sum, range, kurtosis, dan skewness (kemencengan distribusi) (Ghozali, 2013:19). Apabila nilai rata-rata (mean) lebih besar daripada standar deviasi maka kualitas data adalah lebih baik.Pada penelitian ini statistik deskriptif akan menggambarkan deskripsi dari masingmasing variabel.

Tabel 1. Hasil Uji Statistik Deskriptif

Descriptive Statistics

\begin{tabular}{|l|l|l|l|l|l|}
\hline & $\mathrm{N}$ & Minimum & Maximum & Mean & Std. Deviation \\
\hline DA & 40 & $-404473144,00$ & 154782118,00 & $-5885416,9000$ & 95746453,18679 \\
LEV & 40 & 25,00 & 837,00 & 78,9500 & 124,24004 \\
LNA & 40 & 225336759,00 & 2367446151,00 & 1944387383,5250 & 619748285,65448 \\
$\begin{array}{l}\text { Valid N } \\
\text { (listwise) }\end{array}$ & 40 & & & & \\
\hline
\end{tabular}

1) Leverage(X1)

Hasil analisis statistik deskriptif terhadap variabel leverage (X2) menunjukkan nilai minimum sebesar 25,00 dan nilai maksimum sebesar 837,00 dengan nilai rata-rata (mean) sebesar 78,9500 dengan standar deviasi sebesar 124,24004.

2) Ukuran Perusahaan(X2)

Hasil statistik deskriptif terhadap variabel ukuran perusahaan (X2) menunjukkan nilai minimum sebesar 225336759,00 dan nilai maksimum sebesar 2367446151,00 dengan nilai rata-rata (mean) sebesar 1944387383,5250 dan standar deviasi sebesar 6197482285,65448.

3) Manajemen Laba (Y)

Hasil analisis statistik deskriptif terhadap variabel manajemen laba (Y) menunjukkan nilai minimum sebesar -404473144 dan nilai maksimum sebesar 154782118 dengan nilai rata-rata (mean) sebesar $-5885416,9$ dan standar deviasi sebesar 95746453,18. Nilai negatif yang terlihat pada nilai minimum menunjukkan bahwa perusahaan melakukan manajemen laba dengan cara menurunkan labanya. Sedangkan nilai discretionary accruals positif menggambarkan perusahaan melakukan manajemen laba dengan cara menaikkan labanya.

\section{Hasil Uji AsumsiKlasik}

\section{a. UjiMultikolonieritas}

Tabel 2. Uji Multikolonieritas Coefficients $^{\mathrm{a}}$

\begin{tabular}{|ll|l|l|}
\hline \multicolumn{2}{|l|}{ Model } & & \multicolumn{2}{|l|}{ Collinearity Statistics } \\
\cline { 3 - 4 } & & Tolerance & VIF \\
\hline \multirow{2}{*}{1} & LEV &, 998 & 1,002 \\
& LNAsset &, 998 & 1,002 \\
\hline
\end{tabular}

a. Dependent Variable: DA 
Berdasarkan tabel 5.3 dapat dilihat bahwa leverage (X1) dan ukuran perusahaan (X2) menunjukkan nilai tolerance senilai 0,998 lebih besar dari 0,10 dan VIF senilai 1,002 lebih kecil dari 10 telah sesuai dengan syarat yang ditentukan. Oleh karena itu dapat disimpulkan bahwa variabel independen yang digunakan dalam model regresi penelitian ini terbebas dari gejalamultikolonieritas. Artinya, tidak terdapat korelasi antar variabel bebas.

\section{b. UjiAutokorelasi}

Tabel 3. UjiAutokorelasi

Model Summary ${ }^{\mathbf{b}}$

\begin{tabular}{|l|l|l|l|l|l|}
\hline Model & $\mathrm{R}$ & $\mathrm{R}$ Square & $\begin{array}{l}\text { Adjusted R } \\
\text { Square }\end{array}$ & $\begin{array}{l}\text { Std. Error of the } \\
\text { Estimate }\end{array}$ & $\begin{array}{l}\text { Durbin- } \\
\text { Watson }\end{array}$ \\
\hline 1 &, $291^{\mathrm{a}}$ &, 085 &, 034 & 94529075,03549 & 1,885 \\
\hline
\end{tabular}

a. Predictors: (Constant), LNAsset, LEV

b. Dependent Variable: DA

Berdasarkan hasil yang ditampilkan dalam Tabel 4.4, dapat dilihat bahwa nilai DW yang dihasilkan sebesar 1,874 . Nilai ini jika dibandingkan dengan menggunakan tabel DW dengan tingkat kepercayaan 5\%, dengan jumlah sampel 40 dengan variabel bebas 2, diperoleh nilai dL sebesar 1.3908 dan nilai dU sebesar 1.6000. Dengan demikian, dapat disimpulkan bahwa tidak terjadi gejala autokorelasi dalam model regresi yang digunakan karena nilai $\mathrm{dL} \leq \mathrm{dw} \leq 4-\mathrm{dU}$ $(1.3908 \leq 1,874 \leq 1.6000)$.

\section{c. UjiHeteroskedastisitas}

Tabel 4. UjiHeteroskedastisitas

Coefficients ${ }^{\mathrm{a}}$

\begin{tabular}{|l|l|l|l|l|l|l|l|l|}
\hline \multirow{2}{*}{ Model } & \multicolumn{2}{|l|}{ Unstandardized Coefficients } & $\begin{array}{l}\text { Standardized } \\
\text { Coefficients }\end{array}$ & $\mathrm{t}$ & \multicolumn{2}{l|}{ Sig. } & \multicolumn{2}{l|}{$\begin{array}{l}\text { Collinearity } \\
\text { Statistics }\end{array}$} \\
\cline { 2 - 4 } & $\mathrm{B}$ & Std. Error & Beta & & & Tolerance & VIF \\
\hline (Constant) & $-250695,195$ & 173165926,184 & &,- 001 &, 999 & & \\
LEV &,- 026 &, 041 &,- 102 &,- 628 &, 534 &, 997 & 1,003 \\
LNAsset &, 057 &, 084 &, 110 &, 673 &, 505 &, 997 & 1,003 \\
\hline
\end{tabular}

a. Dependent Variable: DA

Berdasarkan Tabel 5.5 menunjukkan bahwa nilai signifikansi variabel independen yaitu leverage (X1)dan ukuran perusahaan (X2) berada diatas tingkat tingkatkepercayaan 5\%, sehingga dapat disimplkan bahwa model regresi yang digunakan terbebas dari gejala heteroskedastisitas.

\section{d. Uji Normalitas}

Analisis statistik yang digunakan untuk menguji normalitas data adalah menggunakan metode Kolmogorov-Smirnov. Dengan uji ini dapat diketahui sampel yang diamati terdistribusi secara normal atau tidak. Jika datatersebut mempunyai level of significance sama atau diatas $5 \%(\alpha \geq 0,05)$ maka data tersebut terdistribusi secara normal. Sedangkan jika kurang dari $5 \%(\alpha \leq 0,05)$ maka data tersebut tidak terdistribusi secara normal. 
Tabel 5. Hasil Uji Kolmogorov-Smirnov One-Sample One-Sample Kolmogorov-Smirnov Test

\begin{tabular}{|c|c|c|}
\hline & & $\begin{array}{l}\text { Unstandardized } \\
\text { Residual }\end{array}$ \\
\hline $\begin{array}{l}\text { N } \\
\text { Normal Parameters }{ }^{\mathrm{a}, \mathrm{b}} \\
\text { Most Extreme Differences } \\
\text { Kolmogorov-Smirnov Z } \\
\text { Asymp. Sig. (2-tailed) }\end{array}$ & $\begin{array}{l}\text { Mean } \\
\text { Std. Deviation } \\
\text { Absolute } \\
\text { Positive } \\
\text { Negative }\end{array}$ & $\begin{array}{l}38 \\
339707,1715718 \\
90474180,74158382 \\
, 170 \\
, 133 \\
-, 170 \\
1,046 \\
, 224\end{array}$ \\
\hline
\end{tabular}

a. Test distribution is Normal.

b. Calculated from data.

Berdasarkan hasil pengujian Kolmogorov-Smirnov dapat dilihat nilai signifikansi yang diperoleh sebesar $0,224 \geq 0,05$. Hal ini berarti data yang digunakan terdistribusi secara normal dan dapat dikatakan memenuhi syarat ujinormalitas.

\section{Hasil Uji HipotesisPenelitian}

Pengujian hipotesis dalam penelitian ini dilakukan dengan menggunakan model analisis regresi berganda (multiple regression analysis), yaitu dilakukan melalui uji koefisien determinasi, uji statistik F, dan uji statistikt.

a. Koefisien Determinasi $\left(R^{2}\right)$

Tabel 6. Hasil Uji Koefisien Determinasi Model Summary ${ }^{\text {b }}$

\begin{tabular}{|l|l|l|l|l|l|}
\hline Model & $\mathrm{R}$ & R Square & $\begin{array}{l}\text { Adjusted R } \\
\text { Square }\end{array}$ & $\begin{array}{l}\text { Std. Error of the } \\
\text { Estimate }\end{array}$ & $\begin{array}{l}\text { Durbin- } \\
\text { Watson }\end{array}$ \\
\hline 1 &, $291^{\mathrm{a}}$ &, 085 &, 034 & 94529075,03549 & 1,885 \\
\hline
\end{tabular}

a. Predictors: (Constant), LNAsset, LEV

b. Dependent Variable: DA

Berdasarkan Tabel 5.8 dapat dilihat nilai adjusted $\mathrm{R}^{2}$ sebesar 0,034 . Hal ini berarti sebesar $3,4 \%$ variabel dependen yaitu manajemen laba dapat dijelaskan oleh variabel independen yaitu leverage dan ukuran perusahaan. Sedangkan sisanya sebesar $(96,6 \%)$ dijelaskan oleh faktor-faktor lain yang tidak termasuk dalam analisa regresi yang digunakan dalam penelitian ini.Variabelvariabel lain yang mempengaruhi manajemen laba menurut Ujiyantho dan Pramuka (2007) adalah mekanisme corporate governance. Sedangkan menurut I Guna dan Herawaty (2010) menyatakan bahwa independensi auditor dan kualitas audit mempunyai pengaruh terhadap tindakan manajemen laba. 


\section{b. Uji Signifikansi Simultan (Uji StatistikF)}

Tabel 7. Hasil Uji StatistikF

ANOVA ${ }^{\mathrm{a}}$

\begin{tabular}{|rl|r|r|r|r|r|}
\hline Model & & Sum of Squares & Df & Mean Square & F & Sig. \\
\hline & Regression & 2801460563557 & 2 & 1400730281778 & 1,664 &, $204^{\mathrm{b}}$ \\
& & 5940,000 & 2 & 7970,000 & & \\
1 & Residual & 3030373873181 & 36 & 8417705203281 & & \\
& & 51300,000 & 36 & 980,000 & & \\
& Total & 3310519929537 & 38 & & & \\
& & 27230,000 & 38 & & & \\
\hline
\end{tabular}

a. Dependent Variable: NDA

b. Predictors: (Constant), LNAsset, LEV

Berdasarkan Tabel 5.9 menunjukkan hasil uji statistik $\mathrm{F}$ memiliki nilai probability sebesar 0,204 lebih besar dari 0,05. Maka dapat disimpulkan bahwa seluruh variabel independen yaitu leverage dan ukuran perusahaan secara simultan tidak mempengaruhi variabel dependennya yaitu manajemen laba.

c. Uji Signifikansi Parameter Individual (Uji Statistikt)

Pengujian ini bertujuan untuk menguji pengaruh dari variabel independen yaitu leverage, dan ukuran perusahaan terhadap variabel dependen yaitu manajemen laba.Berikut ini merupakan hasil yang diperoleh dari analisis regresi:

Tabel 8 Hasil Uji Parameter Individual (Uji t)

Coefficients $^{\mathrm{a}}$

\begin{tabular}{|c|c|c|c|c|c|}
\hline \multirow[t]{2}{*}{ Model } & \multicolumn{2}{|c|}{ Unstandardized Coefficients } & Standardized & \multirow[t]{2}{*}{$\mathrm{t}$} & \multirow[t]{2}{*}{ Sig. } \\
\hline & B & Std. Error & Beta & & \\
\hline (Constant) & 13788581,457 & 48949669,092 & & ,282 & ,780 \\
\hline LEV & $-214680,915$ & 118556,146 &,- 289 & $-1,811$ & ,079 \\
\hline LNAsset & &, 024 &,- 023 &,- 143 & ,887 \\
\hline
\end{tabular}

Berdasarkan hasil pengujian diatas, menunjukkan bahwa variabel leverage (X1) berpengaruh positif signifikan terhadap manajemen laba pada level $10 \%$. Sedangkan ukuran perusahan $\left(\mathrm{X}_{2}\right)$ tidak berpengaruh secara signifikan terhadap manajemen laba. Hal tersebut dapat dilihat dari nilai probabilitas yang dihasilkan variabel leverage (X1) sebesar 0,079 , yang lebihkecil dari 0,1 dan nilai probabilitas yang dihasilkan variabel ukuran perusahaan (X2) sebesar 0,887 yang lebih besar dari 0,05 .

Berdasarkan Tabel 5.10 dapat dilihat koefisiensi untuk persamaanregresi berganda pada penelitian ini yang dapat disusun dalam persamaan matematis sebagai berikut:

$\mathrm{DA}=13788581,457-214680,915$ LEV -,003 SIZE+ 48949669,092

Berdasarkan persamaan regresi diatas, dapat diinterpretasikan sebagai berikut:

1. Pada persamaan diatas diperoleh koefisien konstanta sebesar 13788581,457, 
menunjukkan jika variabel independen dianggap tidak ada maka tidak akan terjadi peningkatan manajemen laba sebesar 13788581,457.

2. Koefisien regresi untuk variabel leverage sebesar $-214680,915$, menunjukkan bahwa setiap adanya kenaikan satu tingkatan dari variabel leverage dengan asumsi variabel lain tetap, maka akan menurunkan manajemen laba sebesar214680,915.

3. Koefisien regresi untuk variabel ukuran perusahaan sebesar -,003, menunjukkan bahwa setiap adanya kenaikan satu tingkatan dari variabel ukuran perusahaan dengan asumsi variabel lain tetap, maka akan menurunkan manajemen laba sebesar0,003.

\section{Pembahasan}

\section{a. Pengaruh Leverage Terhadap ManajemenLaba}

Hasil penelitian ini menunjukkan bahwa variabel leveragetidak berpengaruh terhadap penerapan manajemen laba. Hal ini dibuktikan dengan hasil koefisien regresi yang menunjukkan nilai negatif sebesar 214680,915 dengan signifikansi 0,079 yang berada di atas tingkat kepercayaan 5\%. Oleh karena itu dapat dikatakan bahwa variabel leverage tidak berpengaruh signifikan terhadap manajemen laba.

Hal ini mendukung hasil penelitian Gunawan dkk. (2015) yang menyatakan bahwa leverage perusahaan tidak berpengaruh terhadap praktek manajemen melakukan earnings management. Leverage yang digunakan dalam penelitian ini adalah perbandingan antara liabilities (kewajiban) terhadap asset. Semakin besar kewajiban suatu perusahaan dibandingkan dengan assetnya, maka semakin besar risiko yang dihadapi oleh perusahaan untuk membayar kewajibannya. Semakin besar rasio leverage menunjukkan semakin besar tingkat ketergantungan perusahaan terhadap pihak eksternal (kreditur) dan semakin besar pula beban biaya hutang (biaya bunga) yang harus dibayar oleh perusahaan. Dengan semakin meningkatnya rasio leverage (dimana beban hutang juga semakin besar) maka hal tersebut berdampak terhadap profitablitas yang diperoleh perusahaan, karena sebagian digunakan untuk membayar bunga pinjaman.

Berdasarkan teori agensi (agency theory) yang diungkapkan oleh Jensen dan Meckling (1976), perusahaan dengan proporsi hutang yang tinggi dalam struktur pemodalannya akan mempunyai biaya pengawasan (monitoring cost) yang lebih besar. Biaya pengawasan (monitoring cost) ini timbul karena kepentingan pemilik dalam perusahaan tersebut untuk mengawasi tindakan manajemen dalam mengelola dana dan fasilitas yang diberikan oleh pemilik untuk menjalankan perusahaan. Oleh karena itu, perusahaan yang mempunyai leverage yang tinggi mempunyai kewajiban lebih untuk memenuhi kebutuhan informasi yang memadai bagi pemilik, pemegang saham dan kreditur.

Hasil penelitian ini konsisten dengan hasil penelitian yang dilakukan oleh Jao dan Pagalung (2011). Menurutnya, perusahaan dengan tingkat leverage yang tinggi akibat besarnya total hutang terhadap total modal akan menghadapi resiko 
default yang tinggi yaitu perusahaan terancam tidak mampu memenuhi kewajibannya. Tindakan manajemen laba tidak dapat dijadikan sebagai mekanisme untuk menghindarkan default tersebut.Pemenuhan kewajiban harus tetap dilakukan dan tidak dapat dihindarkan dengan manajemen laba.Hasil penelitian yang sama ditemukan oleh oleh Jao dan Pagalung (2011), Prambudi dan Sumantri (2014) serta Setyaningtyas dan Hadiprajitno (2014) yang menyatakan bahwa leverage tidak berpengaruh signifikan terhadap manajemenlaba.

\section{b. Pengaruh Ukuran Perusahaan Terhadap ManajemenLaba}

Hasil penelitian ini menunjukkan bahwa variabel ukuran perusahaan tidak berpengaruh secara signifikan terhadap manajemen laba. Hal ini dibuktikan dengan nilai probabilitas yang diperoleh sebesar 0,887 yang berada diatas tingkat signifikansi 5\%. Artinya ukuran perusahaan secara empiris tidak terbukti berpengaruh terhadap tindakan manajemen laba.Berdasarkan hasil yang diperoleh, maka dapat disimpulkan bahwa Ha2ditolak. Hal ini berarti bahwa ukuran perusahaan yang diukur dengan logaritma natural total asset belum mampu mendeteksi adanya pengaruh terhadap manajemen laba yang dilakukan oleh perusahaan.

Menurut Lusi (2014) pengawasan yang ketat dari pemerintah, analis, dan investor yang ikut menjalankan perusahaan menyebabkan manajer tidak berani melakukan praktik perataan laba yang merupakan salah satu teknik dalam manajemen laba. Halini dikarenakan, dengan pengawasan yang ketat tersebut jika manajer melakukan prakik perataan laba besar kemungkinan akan diketahui oleh pemerintah, analis, dan investor sehingga hal ini dapat merusak citra dan kredibilitas manajer perusahaan tersebut.

Hal ini menunjukkan bahwa ukuran perusahaan belum tentu dapat memperkecil kemungkinan terjadinya manajemen laba. Perusahaan besar memiliki jumalh asset yang lebih banyak dan ada potensi banyak aset yang tidak dikelola dengan baik sehingga kemungkinan kesalahan dalam mengungkapan total aset dalam perusahaan tersebut.

Penelitian ini konsisten dengan penelitian Gunawan dkk (2015) bahwa ukuran perusahaan tidak berpengaruh signifikan terhadap manajemen laba, karena perusahaan yang lebih besar kurang memiliki dorongan untuk melakukan manajemen laba dibandingkan perusahaan-perusahaan kecil dan perusahaan besar dipandang lebih kritis oleh pemegang saham dan pihak luar. Selain itu perusahaan besar kurang melakukan perataan laba dibandingkan dengan perusahaan-perusahaan yang lebih kecil karena perusahaan-perusahaan besar menjadi subyek pemeriksaan (pengawasan yang lebih ketat dari pemerintah dan masyarakat umum/publik). Hasil penelitian ini didukung oleh Lusi (2014), Gunawan dkk (2015) , Siti Nayiroh (2013), dan Setyaningtyas dan Hadiprajitno (2014) yang juga menyatakan ukuran tidak berpengaruh signifikan terhadap manajemen laba. 


\section{KESIMPULAN DAN SARAN}

\section{Kesimpulan}

Penelitian ini menguji pengaruh leverage dan ukuran perusahaan sebagai variabel independen (bebas) terhadap manajemen laba sebagai variabel dependen (terikat). Analisis yang digunakan dalam penelitian ini yaitu analisis statistik deskriptif dan analisis regresi berganda, dan menggunakan uji asumsi klasik untuk menguji kelayakan dari model regresi yang digunakan.Data sampel yang digunakan adalah perusahaan pertambangan dan konstruksi yang terdaftar di BEI selama periode2010-2015.

Berdasarkan hasil penemuan dan pembahasan pada bab sebelumnya, dapat diambil beberapa kesimpulan atas penelitian ini, yaitu:

1. Variabel leverage tidak berpengaruh signifikan terhadap manajmen laba pada suatu perusahaan. Hasil penelitian ini konsisten dengan hasil penelitian yang dilakukan oleh Jao dan Pagalung (2011), Prambudi dan Sumantri (2014) serta Setyaningtyas dan Hadiprajitno (2014) yang menyatakan bahwa leverage tidak berpengaruh signifikan terhadap manajemenlaba.

2. Variabel ukuran perusahaan tidak berpengaruh signifikan terhadap manajemen laba pada suatu perusahaan. Hasil penelitian ini konsisten dengan penelitian yang dilakukan oleh Lusi (2014), Gunawan dkk (2015), Siti Nayiroh (2013), dan Setyaningtyas dan Hadiprajitno (2014) yang juga menyatakan ukuran tidak berpengaruh signifikan terhadap manajemenlaba.

\section{Saran}

Penelitian mengenai manajemen laba selanjutnya dimasa yang akan datang diharapkan mampu menghasilkan hasil yang lebih baik dan nyata yang benar- benar mencerminkan keadaan yang sebenarnya, dengan mempertimbangkan beberapa saran sebagai berikut:

1) Penelitian selanjutnya disarankan untuk meneliti lebih dalam mengenai faktor-faktor yang dapat mempengaruhi manajemen laba dengan menggunakan variabel independen yang berbeda, seperti menggunakan variabel good corporate governance yang secara teori diharapkan dapatmengurangi penerapan manajemen laba atau peneliti dapat memilih variabel lain yang diperkirakan berhubungan dengan praktik manajemen laba tersebut.

2) Penelitian selanjutnya diharapkan dapat menggunakan proksi lain yang dianggap lebih baik dalam mendeteksi tindak manajemen laba yang dilakukan oleh perusahaan. 
3) Penelitian selanjutnya diharapkan dapat memperluas penggunaan sampel agar hasil penelitian dapat digeneralisasi, seperti menggunakan seluruh perusahaan yang terdaftar di BEI yang terdiri dari berbagai macam sektor disertai denganrentang waktu penelitian yang lebihpanjang.

\section{DAFTAR PUSTAKA}

Agustina, Dian. 2013. Pengaruh Faktor Good Corporate Governance, Free Cash Flow, dan Leverage Terhadap Manajemen Laba. Jurnal Akuntansi dan Keuangan, 15 (1), 27-42

Ajit, Malik, S. \& Verma, V.K. 2013.Earnings Management in India. University of Northern British Columbia, Canada

Ardekani, A. Mahdavi., Younesi, N.,\& Hashemijoo, M. 2012. Acquisition, Earnings Management and Firm's Performance: Evidence from Malaysia. Journal of Business Studies Quarterly, 4 (1), 91-110

Atmaja, Lukas Setia. (2002). Manajemen Keuangan.Yogyakarta : Penerbit Andi

Azhari, Andy. 2015. Pengaruh Struktur Modal dan Manajemen Laba Terhadap Pajak Penghasilan Badan Terutang. Universitas Islam Negeri Syarif Hidayatullah, Jakarta

Brealey, R. A., Myers, S. C., \& Marcus, A. J. 2007.Dasar-Dasar Manajemen Keuangan Perusahaan. Erlangga, Jakarta

Bruns Jr, W. J., \& Merchant, K. A. (2005).The dangerous morality of managing earnings.Accounting ethics: critical perspectives on business and management, 2(2), 90.

Burgstahler, D., Hail, L., \& Leuz, C,. 2004. Earnings Management in European Private and Public Firms. The Wharton Financial Institutions Center, Pennsylvania

Burgstahler, D., \& Chuk, E. 2012. What we have learned About Earnings Management? Correcting Disinformation about Discontinuities. University of Washington

Dechow, P.M., \& Skinner, D. J. 2000. Earnings Management: Reconciling the Views of Accounting Academics, Practitioners, and Regulators. Accounting Horizons, 14 (2), 235-250

Deegan, Craig. 2007. Financial Accounting Theory, Second Edition. McGraw Hill, Australia 
Guna, Welvin dan Herawaty, Arleen. 2010. Pengaruh Mekanisme Good Corporate Governance, Independensi Auditor, Kualitas Audit dan Faktor Lainnya Terhadap Manajemen Laba. Jural Bisnis dan Akuntansi 12(1), 53-68

Gunawan, I K., Darmawan, N.A.S., dan Purnamawati, G.A. 2015. Pengaruh Ukuran Perusahaan, Profitabilitas, dan Leverage Terhadap Manajemen Laba pada Perusahaan Manufaktur yang Terdaftar di Bursa Efek Indonesia (BEI). E-Journal S1 Ak Universitas Pendidikan Vol. 03, No.01

Hartanto, Dedy dan Yeterina Widi Nugrahanti.2012. Pengaruh Struktur Kepemilikan dan Struktur Modal Terhadap Manajemen Laba. Fakultas Ekonomika dan Bisnis Universitas Kristen Satya Wacana

Ikatan Akuntan Indonesia. 2009. Standar Akuntansi Keuangan. Salemba Empat, Jakarta

Juniarti dan Corolina.2005. Analisis Faktor-Faktor yang Berpengaruh Terhadap Perataan Laba (Income Smoothing) Pada Perusahaan-Perusahaan Go Public. Jurnal Ekonomi Akuntansi. Fakultas Ekonomi Universitas Kristen Petra. Surabaya

Jao, Robert dan Pagalung, Gagaring. 2011. Corporate Governance, Ukuran Perusahaan, dan Leverage Terhadap Manajemen Laba Perusahaan Manufaktur Indonesia. Jurnal Akuntansi dan Auditing Vol. 8 No. 1: 1-94

Nayiroh, Siti. 2013. Analisis Faktor-Faktor yang Mempengaruhi Praktik Manajemen Laba.E-Journal Universitas Dian Nuswantoro.

Prambudi, E. Januar dan Sumantri, A. Farid. 2014. "Kualitas Audit, Ukuran Perusahaan, dan Leverage Terhadap Manajemen Laba". SNA XVII Mataram.

Scott, W. R. 2009. Financial Accounting Theory. Pearson Prentice Hall, United States of America

Setyaningtyas, Ina dan Hadiprajitno, Basuki. 2014. "Analisis Faktor-Faktor yang Mempengaruhi Perataan Laba (Income Smoothing)". Diponegoro Journal Of Accounting Vol. 03 No. 02.

Sulistyanto, H. Sri. 2008. Manajemen Laba Teori dan Model Empiris. Grasindo, Jakarta

Ujah, Nacasius. U. \& Brusa, Jorge O. 2010. The Effect of Financial Leverage and Cash Flow Volatility on Earnings Management. Texas A\&M International University

Ujiyantho, M. Arief dan Pramuka, B. Agus (2007). Mekanisme Corporate Governance, Manajemen Laba dan Kinerja Keuangan. Simposium Nasional Akuntansi X 
Warianto, Paulina. 2015. Pengaruh Ukuran Perusahaan, Struktur Modal Likuiditas dan Investment Opportunity Set (IOS) Terhadap Kualitas Laba pada Perusahaan Manufaktur yang terdaftar di BEI. Universitas Atma Jaya, Yogyakarta

Wibisana, Imas D. dan Ratnaningsih, D. 2014.Analisis Faktor-Faktor yang Mempengaruhi Arah Manajemen Laba. Fakultas Ekonomi, Universitas Atma Jaya Yogyakarta

Yatulhusma, Najmi.2015. Pengaruh Profitabilitas, Leverage, Umur dan Ukuran Perusahaan Terhadap Manajemen Laba. UIN Syarif Hidayatullah 